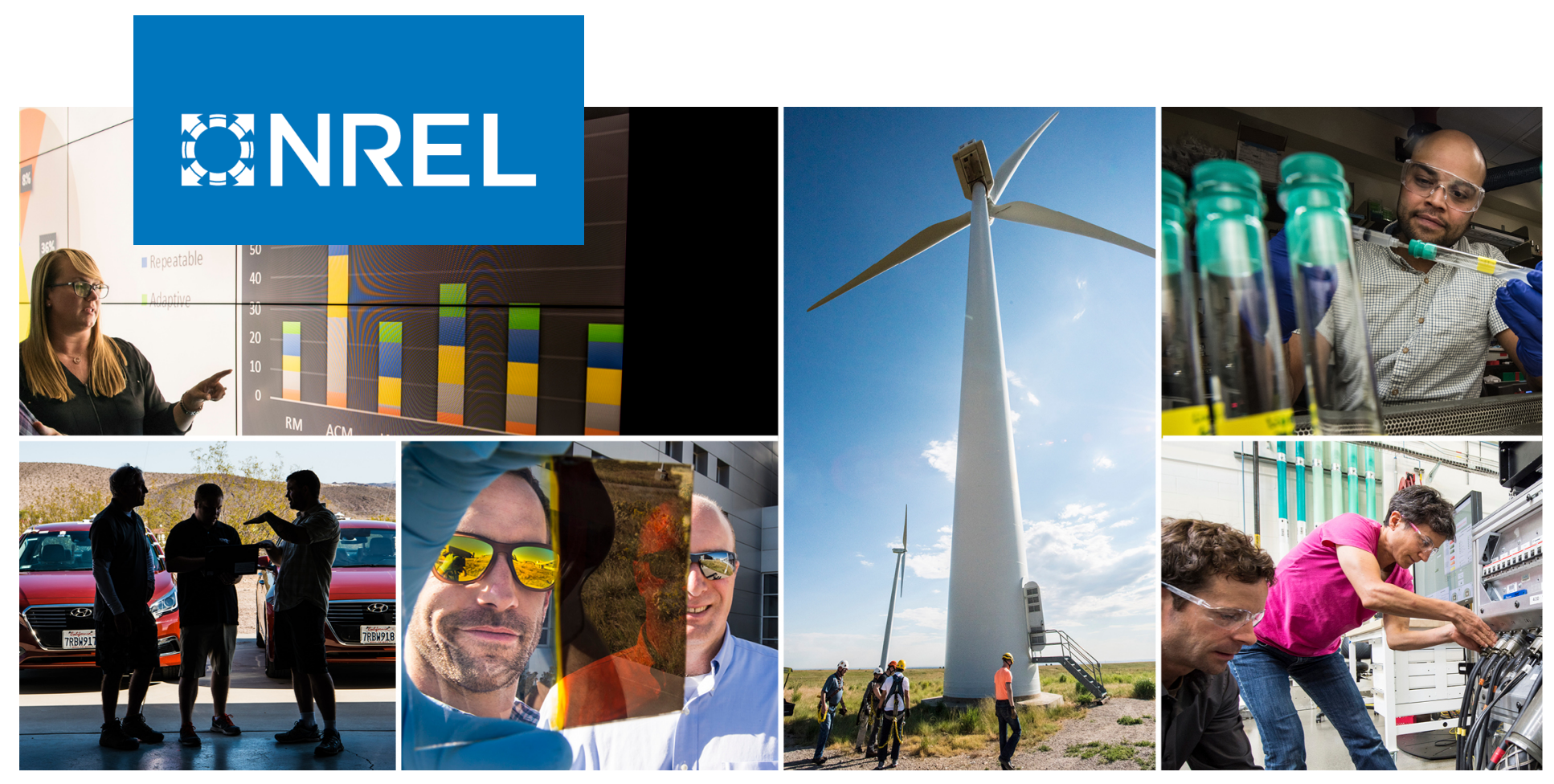

\title{
Advanced Energy Approaches for Mixed-Use Developments in the Front Range Urban Corridor
}

Ben Polly, ${ }^{1}$ Shanti Pless, ${ }^{1}$ Otto VanGeet, ${ }^{1}$ and Timothy Rehder ${ }^{2}$

1 National Renewable Energy Laboratory

2 U.S. Environmental Protection Agency

NREL is a national laboratory of the U.S. Department of Energy Office of Energy Efficiency \& Renewable Energy

Operated by the Alliance for Sustainable Energy, LLC

This report is available at no cost from the National Renewable Energy Laboratory (NREL) at www.nrel.gov/publications.
Technical Report

NREL/TP-5500-77847

February 2021 


\title{
GNREL
}

\section{Advanced Energy Approaches for Mixed-Use Developments in the Front Range Urban Corridor}

\author{
Ben Polly, ${ }^{1}$ Shanti Pless, ${ }^{1}$ Otto VanGeet, ${ }^{1}$ and \\ Timothy Rehder ${ }^{2}$
}

\author{
1 National Renewable Energy Laboratory \\ 2 U.S. Environmental Protection Agency
}

\section{Suggested Citation}

Polly, Ben, Shanti Pless, Otto VanGeet, and Timothy Rehder. 2021. Advanced Energy Approaches for Mixed-Use Developments in the Front Range Urban Corridor. Golden, CO: National Renewable Energy Laboratory. NREL/TP-5500-77847.

https://www.nrel.gov/docs/fy21osti/77847.pdf.

NREL is a national laboratory of the U.S. Department of Energy Office of Energy Efficiency \& Renewable Energy Operated by the Alliance for Sustainable Energy, LLC

This report is available at no cost from the National Renewable Energy Laboratory (NREL) at www.nrel.gov/publications.

Contract No. DE-AC36-08G028308
Technical Report NREL/TP-5500-77847

February 2021

National Renewable Energy Laboratory 15013 Denver West Parkway Golden, CO 80401 303-275-3000 • www.nrel.gov 


\section{NOTICE}

This work was authored in part by the National Renewable Energy Laboratory, operated by Alliance for Sustainable Energy, LLC, for the U.S. Department of Energy (DOE) under Contract No. DE-AC36-08GO28308. Funding provided by the U.S. Environmental Protection Agency. The views expressed herein do not necessarily represent the views of the DOE or the U.S. Government.

This report is available at no cost from the National Renewable Energy Laboratory (NREL) at www.nrel.gov/publications.

U.S. Department of Energy (DOE) reports produced after 1991 and a growing number of pre-1991 documents are available free via www.OSTI.gov.

Cover Photos by Dennis Schroeder: (clockwise, left to right) NREL 51934, NREL 45897, NREL 42160, NREL 45891, NREL 48097, NREL 46526.

NREL prints on paper that contains recycled content. 


\section{Acknowledgments}

The authors would like to thank Chris Parr of Sun Valley EcoDistrict Trust for providing information, insights, and suggestions related to Sun Valley and mixed-used development considerations in the Front Range. 


\section{List of Acronyms}

ACH50

Amp

COBECC

CNI

DOE

EDA

EPA

EUI

EV

EVSE

HUD

HVAC

HRV

IECC

LED

LEED

MERV

MFSD

NREL

PRPA

PV

REC

TOU

$\mathrm{V}$ air changes per hour at 50 pascals

ampere

City of Boulder Energy Conservation Code

Choice Neighborhood Initiative

U.S. Department of Energy

Energy Design Assistance

U.S. Environmental Protection Agency

energy use intensity

electric vehicle

electric vehicle supply equipment

U.S. Department of Housing and Urban Development

heating, ventilating, and air conditioning

heat recovery ventilator

International Energy Conservation Code

light emitting diode

Leadership in Energy and Environmental Design

Minimum Efficiency Reporting Value

Metropolitan Football Stadium District

National Renewable Energy Laboratory

Platte River Power Authority

photovoltaic

Renewable Energy Certificate

time of use

volt 


\section{Executive Summary}

The primary objective of the document is to present example technical approaches and strategies that planners and developers can reference for all-electric mixed-use developments in the Rocky Mountain Front Range urban corridor that are considering advanced energy performance goals such as high levels of energy efficiency and renewable integration. The strategies are tailored toward the vision for a zero energy, all-electric, district thermal system-connected starter district. In this example, on-site solar generation is emphasized as a strategy that can be combined with electrical and thermal energy storage for enhanced community resilience and demand flexibility. Opportunities for utilizing or adapting these strategies include:

- Sharing with vertical developers for potential integration of strategies into vertical design guidelines

- Incorporation into Owner Project Requirements (OPRs)

- Providing example strategies to design teams as a starting point for design

- Informing structure of agenda for a building design charrette

- Comparing building designs to example strategies at various points in the design process to evaluate design progression.

While the technical strategies outlined in this document can help inform the development of guidelines for projects in the Front Range urban corridor, this document does not set requirements for any rating, certification, program, or policy. ${ }^{1}$

\footnotetext{
${ }^{1}$ For example, this document does not specify requirements for reaching zero energy or calculating emissions in mixed-fuel districts. An example zero energy district calculation for an all-electric district is provided in Appendix A for illustrative purposes only.
} 


\section{Table of Contents}

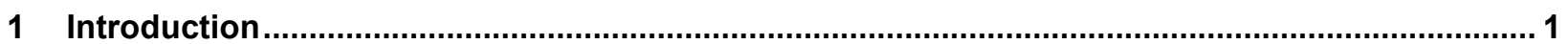

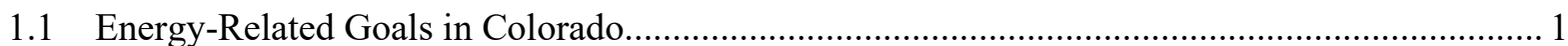

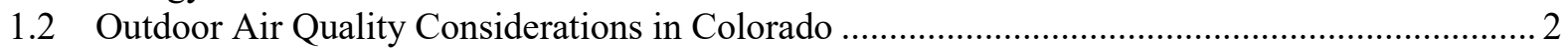

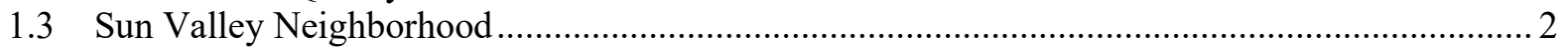

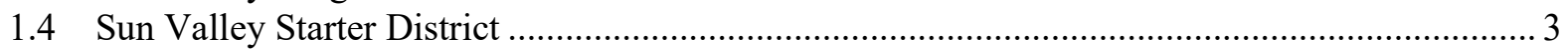

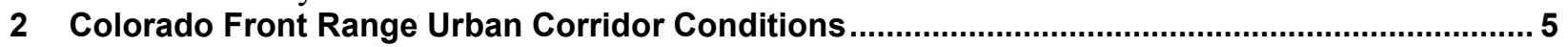

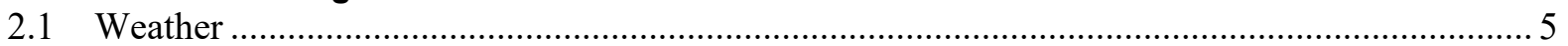

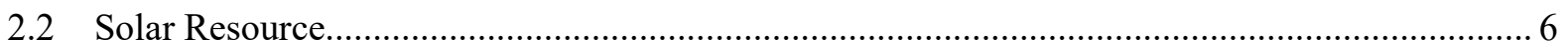

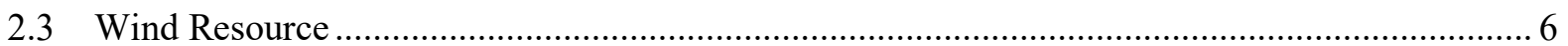

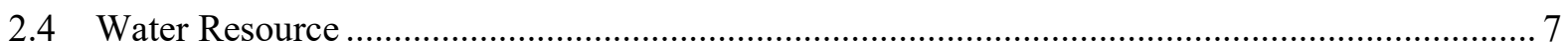

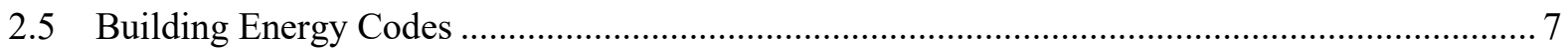

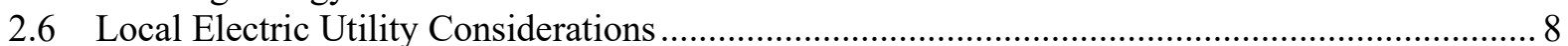

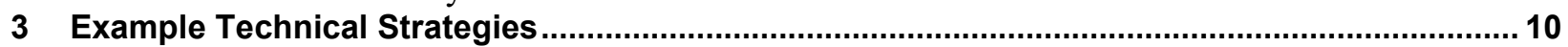

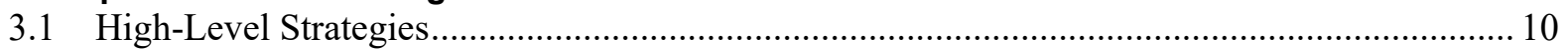

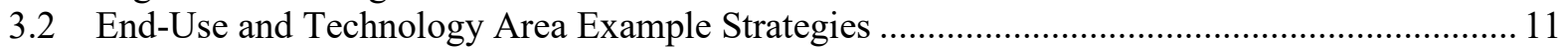

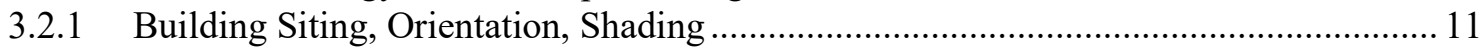

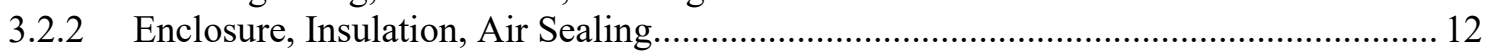

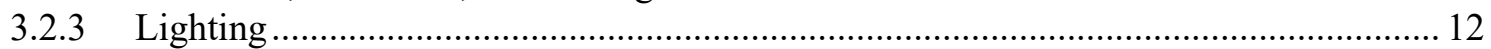

3.2.4 Appliances, Equipment, and Miscellaneous Electric Loads .................................... 12

3.2.5 Domestic Hot Water and Heating, Ventilating, and Air Conditioning ......................... 13

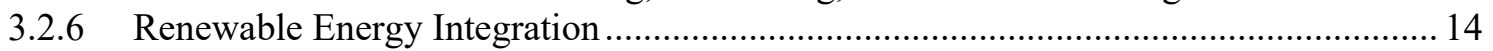

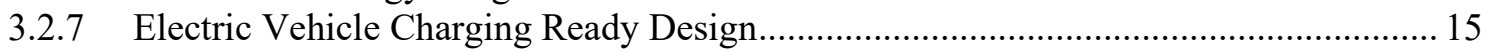

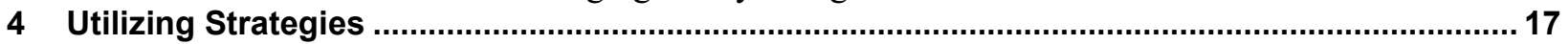

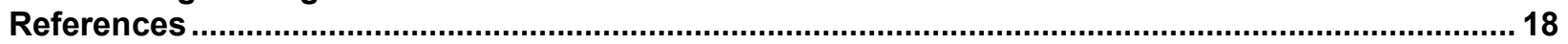

Appendix A. Example Zero Energy Calculation for an All-Electric District ....................................22

Appendix B. Locating Solar Photovoltaic and Renewable Systems .............................................. 26 


\section{List of Figures}

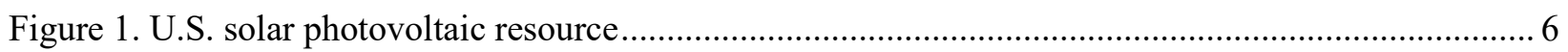

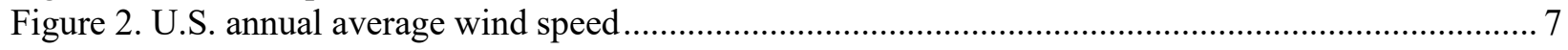

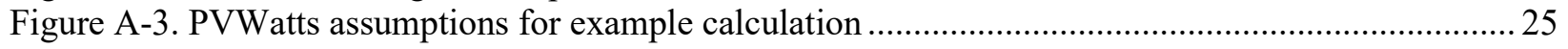

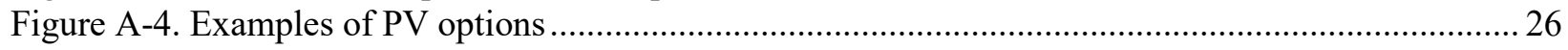

\section{List of Tables}

Table 1. Denver Average Temperatures and Precipitation .................................................................. 5

Table A-2. Example Three-Building Starter District .......................................................................... 23

Table A-3. Summary of Zero Code Renewable Energy Allocation for On-Site and Off-Site Renewable

Options. 


\section{Introduction}

The "Front Range urban corridor," which includes 18 counties in Colorado and Wyoming, grew in population by approximately $16 \%$ between 2010 and 2019 according to U.S. census data (U.S. Census Bureau 2020). During that time, housing supply did not increase at the same rate, and due to a variety of contributing factors, there is currently demand for more affordable housing in much of the Front Range urban corridor (Newcomer and Resnick 2018).

In many mixed-use developments, multifamily housing represents a substantial amount of new square footage being built in the Front Range region. For example, in 2018 over 12,300 apartment units were added in the Denver Metro area, which was nearly three times the average annual rate for the previous 30 years (Svaldi 2019). Multifamily projects in the Front Range typically take the form of low- or mid-rise apartments rather than high-rise apartments, which are more common in denser urban areas. Apartment buildings can be mixed-use, such as those with commercial tenants (e.g., retail, office, food service) at the street level and apartment units on upper floors. Mixed-use apartment buildings can also be part of a broader mixed-use community or district development, whether it is a new greenfield development or urban infill/brownfield redevelopment, helping create walkable/bikeable, engaging, and dynamic communities.

Some community- and district-scale projects in the Front Range are setting advanced energy goals with specific targets for energy efficiency and renewable energy integration (Pless, Polly, and Zaleski 2018). They are considering technical approaches such as best-in-class building efficiency, heat pump-based district thermal systems, on-site solar photovoltaics, and electrochemical battery storage. Approaching energy goals at a community scale rather than an individual building scale can lead to additional opportunities to realize the benefits of integrated design. Additionally, there are unique energy opportunities that can be accessed at a multibuilding scale, such as recovering heat that is rejected from certain buildings or nearby industrial processes and using it in other buildings; centralized energy production and storage; and multibuilding microgrids.

For advanced energy communities in the Front Range there is potential to align energy goals with other benefits such indoor and outdoor air quality, resilience, and economic development. ${ }^{2}$ Understanding and maximizing the co-benefits of advanced energy approaches, especially in low-income and disadvantaged communities, can provide lasting quality-of-life benefits to residents and surrounding communities.

\subsection{Energy-Related Goals in Colorado}

A variety of state, county, city, and utility goals related to energy efficiency, renewable energy, and emissions reductions have been set in Colorado in recent years. For example, Xcel Energy, the largest electric investor owned utility in Colorado, intends to reduce carbon emissions by 80\% relative to 2005 levels by 2030 (Xcel Energy 2020a). The Platte River Power Authority (PRPA), which serves the Front Range urban corridor cities of Fort Collins, Longmont, and Loveland, has committed to $100 \%$ non-carbon energy sources by 2030 (PRPA 2018). The City

\footnotetext{
${ }^{2}$ E.g., alignment with potential occupant/tenant sustainability goals to attract potential additional investment.
} 
and County of Denver has set a goal of an $80 \%$ reduction in greenhouse gas emissions by 2050 relative to 2005 levels (City of Denver 2018a), with the following interim goals that are relevant to mixed-use multifamily developments (City of Denver 2018b):

- Commercial buildings: $30 \%$ reduction in energy use by 2030

- New buildings: Net zero energy by 2035.

In 2019 the Colorado State Legislature passed HB-1291, which sets statewide goals to "reduce 2025 greenhouse gas emissions by at least $26 \%, 2030$ greenhouse gas emissions by at least $50 \%$, and 2050 greenhouse gas emissions by at least $90 \%$ of the levels of statewide greenhouse gas emissions that existed in 2005" (Colorado General Assembly 2019).

While many goals have been set at the state, city, and utility levels in Colorado, their full effects on building- and community-scale efficiency and renewable energy approaches remain to be seen. In this sense, many developments setting advanced energy goals are pushing ahead to achieve a vision for high energy efficiency and renewable energy integration, but at a smaller scale. The example technical approaches and strategies in this document are tailored to such efforts for mixed-use developments at community and district scales.

\subsection{Outdoor Air Quality Considerations in Colorado}

Air pollution in Colorado comes from many different sources, including electricity generation, oil and gas operations, cars and trucks, airplanes, trains, and wildfires. While the trends for a few air pollutants have been positive, some areas of the state still experience poor air quality, including high concentrations of ground level ozone and particulate matter. This is due to certain industrial activities, increasing vehicle miles traveled, local geography, increased wildfires, and rising temperatures. Zero energy districts could help alleviate some of these concerns in specific areas by reducing consumption of traditional grid power, leading to reduced emissions from coal- and gas-fired electric generating stations.

\subsection{Sun Valley Neighborhood}

The Sun Valley neighborhood in Denver, Colorado is bordered on the east by the South Platte River, on the south by 6th Avenue, on the west by Federal Boulevard, and on the north by 20th Avenue. The overall Sun Valley neighborhood is approximately 400 acres, with approximately 33 acres of concentrated public housing in the southern portion of the neighborhood owned by the Housing Authority of the City and County of Denver. Sun Valley is also home to the Denver Broncos Football Club and the Metropolitan Football Stadium District (MFSD) near the northern boundary. Sun Valley is uniquely positioned in the Denver urban core with proximity to the Auraria Campus, home to three higher education institutions, as well as to the lower downtown areas. Over time this neighborhood has served different roles and is preparing for its next chapter in the Denver story.

The Sun Valley neighborhood has suffered from several decades of disinvestment. The mix of industrial, residential, and vacant parcels create what the Decatur Federal Station Area Plan described as varied land uses resulting in "multiple Sun Valleys" that need to be synthesized into 
a coherent neighborhood development plan (City of Denver 2013). Multiple planning studies have been conducted for the neighborhood:

- Two Urban Land Institute Technical Assistance Panels

- The Decatur-Federal Station Area Plan (adopted by Denver City Council in 2013)

- A General Development Plan by the City of Denver, completed in 2014

- A U.S. Department of Housing and Urban Development (HUD) Choice Neighborhood Initiative (CNI) Transformation Plan, completed in 2015

- The Federal Boulevard Improvement Plan

- A HUD CNI Master Plan (part of a CNI grant award to the Housing Authority of the City and County of Denver) in 2016

- A 13th Avenue Realignment Preferred Alternative Plan, completed in 2017

- An MFSD Metro District Plan (adopted by Denver City Council in 2018)

- The recent City of Denver Stadium Area Plan for the MFSD (adopted by Denver City Council in 2019).

Several other related plans, including adjacent waterway and river improvement plans, have also been completed.

As outlined above, the planning has been extensive, but the neighborhood is now at the point where these plans are starting to go vertical with the construction of new buildings. Some existing buildings have been privately purchased and repurposed. Private new development is also taking place, and the first housing phase under the HUD CNI grant is under construction. Many of the mixed-income affordable housing units are being designed with energy efficiency measures and will be constructed as solar-ready. High construction costs, decreased energy implementation incentives, and the lack of an existing regulatory framework for distributing locally-generated energy across rights of way have created barriers to urban in-fill district systems in Sun Valley. However, scientists and researchers from the U.S. Environmental Protection Agency (EPA) and the National Renewable Energy Laboratory (NREL) continue to work with area partners to explore creative and practical strategies. Analysis of smaller zones with contiguous site control remains of interest. Such zones, where 3-5 buildings can share district-based solutions, will remain under review. While new construction in Sun Valley has started, the complete build-out will easily span over 10 years.

\subsection{Sun Valley Starter District}

Smaller zones with the potential for contiguous site control have been identified within Sun Valley and will be modeled. These sites offer opportunities to implement advanced energy approaches on a campus under single ownership with a high level of predictable control. This potential has seeded the consideration of a "starter district" within the broader Sun Valley redevelopment project.

As a visioning exercise, the project team has explored what technical strategies may be needed to achieve a mixed-use development with the following features:

- Zero energy district

- All electric buildings and district — including space heating, hot water, and cooking 
- District thermal energy using an ambient loop connected to the building space conditioning systems (for example, see Linsley-Hood 2020)

- On-site solar photovoltaics (PV)

- Electric vehicle integration

- Enhanced resilience

- Enhanced indoor air quality.

Considering energy strategies early in the development timeline can help increase the likelihood of achieving more advanced goals. For example, development projects often establish design guidelines for individual building vertical development. Some developments have included advanced building energy efficiency, solar PV, and district thermal system interconnection requirements in such guidelines to help ensure that the overall energy vision for the development is achieved as buildings are constructed. The technical strategies outlined in this document can help inform the development of guidelines for projects in the Front Range urban corridor. However, this document does not set requirements for any rating, certification, program, or policy. For example, this document does not specify requirements for reaching zero energy or calculating emissions in mixed-fuel districts. An example zero energy district calculation for an all-electric district is provided in Appendix A for illustrative purposes only. 


\section{Colorado Front Range Urban Corridor Conditions}

This section describes some of the key conditions in the Front Range urban corridor that should be considered when defining advanced energy approaches for mixed-use developments, including weather, natural resources (solar, wind, water), building energy codes, and local electric utility considerations.

\subsection{Weather}

The Front Range urban corridor of Colorado is generally a semi-arid climate. The counties within the corridor fall within the International Energy Conservation Code (IECC) climate zone 5B (cold, dry) or the Building America "Cold" climate zone, which is defined as "A region with between 5,400 and 9,000 heating degree days ( $65^{\circ} \mathrm{F}$ basis)" (Baechler et al. 2015). As seen in Table 1, winters in Denver are milder than some might expect with average daily high temperatures in the mid- to upper 40s ( ${ }^{\circ} \mathrm{F}$ )(VISIT DENVER 2020). Related to the arid climate and relatively low average humidity levels, the region experiences a relatively large average temperature swing between daily high and low temperatures. For example, even during the hottest months of the year, temperatures at night can often be in the $50 \mathrm{~s}$ or $60 \mathrm{~s}\left({ }^{\circ} \mathrm{F}\right)$, which provides opportunities for nighttime ventilation cooling. Lower humidity levels and dew point temperatures also present opportunities for evaporative cooling, but associated water consumption must be considered (see Section 2.4, Water Resource, for discussion of water conservation).

Table 1. Denver Average Temperatures and Precipitation Source: VISIT DENVER 2020

\begin{tabular}{llll}
\hline Month & $\begin{array}{l}\text { Average High } \\
\text { Temperature }\end{array}$ & $\begin{array}{l}\text { Average Low } \\
\text { Temperature }\end{array}$ & $\begin{array}{l}\text { Average } \\
\text { Precipitation }\end{array}$ \\
\hline January & $47^{\circ} \mathrm{F} / 8.3^{\circ} \mathrm{C}$ & $16^{\circ} \mathrm{F} /-8.9^{\circ} \mathrm{C}$ & $0.64 \mathrm{in} . / 16.3 \mathrm{~mm}$ \\
February & $49^{\circ} \mathrm{F} / 9.4^{\circ} \mathrm{C}$ & $18^{\circ} \mathrm{F} /-7.9^{\circ} \mathrm{C}$ & $0.73 \mathrm{in} . / 18.5 \mathrm{~mm}$ \\
March & $56^{\circ} \mathrm{F} / 13.3^{\circ} \mathrm{C}$ & $25^{\circ} \mathrm{F} /-3.9^{\circ} \mathrm{C}$ & $1.88 \mathrm{in} . / 47.8 \mathrm{~mm}$ \\
April & $62^{\circ} \mathrm{F} / 16.7^{\circ} \mathrm{C}$ & $33^{\circ} \mathrm{F} / 0.6^{\circ} \mathrm{C}$ & $2.20 \mathrm{in} . / 55.9 \mathrm{~mm}$ \\
May & $72^{\circ} \mathrm{F} / 22.2^{\circ} \mathrm{C}$ & $42^{\circ} \mathrm{F} / 5.2^{\circ} \mathrm{C}$ & $2.56 \mathrm{in} . / 65 \mathrm{~mm}$ \\
June & $81^{\circ} \mathrm{F} / 27.2^{\circ} \mathrm{C}$ & $50^{\circ} \mathrm{F} / 10^{\circ} \mathrm{C}$ & $2.05 \mathrm{in} . / 52.1 \mathrm{~mm}$ \\
July & $88^{\circ} \mathrm{F} / 31.1^{\circ} \mathrm{C}$ & $56^{\circ} \mathrm{F} / 13.3^{\circ} \mathrm{C}$ & $1.68 \mathrm{in} . / 42.7 \mathrm{~mm}$ \\
August & $86^{\circ} \mathrm{F} / 30^{\circ} \mathrm{C}$ & $54^{\circ} \mathrm{F} / 12.2^{\circ} \mathrm{C}$ & $2.01 \mathrm{in} . / 51.1 \mathrm{~mm}$ \\
September & $78^{\circ} \mathrm{F} / 25.6^{\circ} \mathrm{C}$ & $44^{\circ} \mathrm{F} / 6.7^{\circ} \mathrm{C}$ & $1.13 \mathrm{in} . / 28.7 \mathrm{~mm}$ \\
October & $66^{\circ} \mathrm{F} / 18.9^{\circ} \mathrm{C}$ & $33^{\circ} \mathrm{F} / 0.6^{\circ} \mathrm{C}$ & $1.43 \mathrm{in} . / 36.3 \mathrm{~mm}$ \\
November & $54^{\circ} \mathrm{F} / 12.2^{\circ} \mathrm{C}$ & $23^{\circ} \mathrm{F} /-5^{\circ} \mathrm{C}$ & $1.09 \mathrm{in} . / 27.7 \mathrm{~mm}$ \\
December & $46^{\circ} \mathrm{F} / 7.8^{\circ} \mathrm{C}$ & $16^{\circ} \mathrm{F} /-8.9^{\circ} \mathrm{C}$ & $0.83 \mathrm{in} . / 21.1 \mathrm{~mm}$ \\
\hline
\end{tabular}




\subsection{Solar Resource}

The Front Range urban corridor has a strong solar resource and potential for energy generation via solar PV, as seen in Figure 1 (NREL 2020a). The relatively high number of days of sunshine per year is also a key consideration for building design, as appropriate seasonal shading and passive solar heating can be important strategies for the management and utilization of solar heat gains in high performance buildings. Natural lighting and glare control are also key strategies for utilizing and managing visible solar light gains.

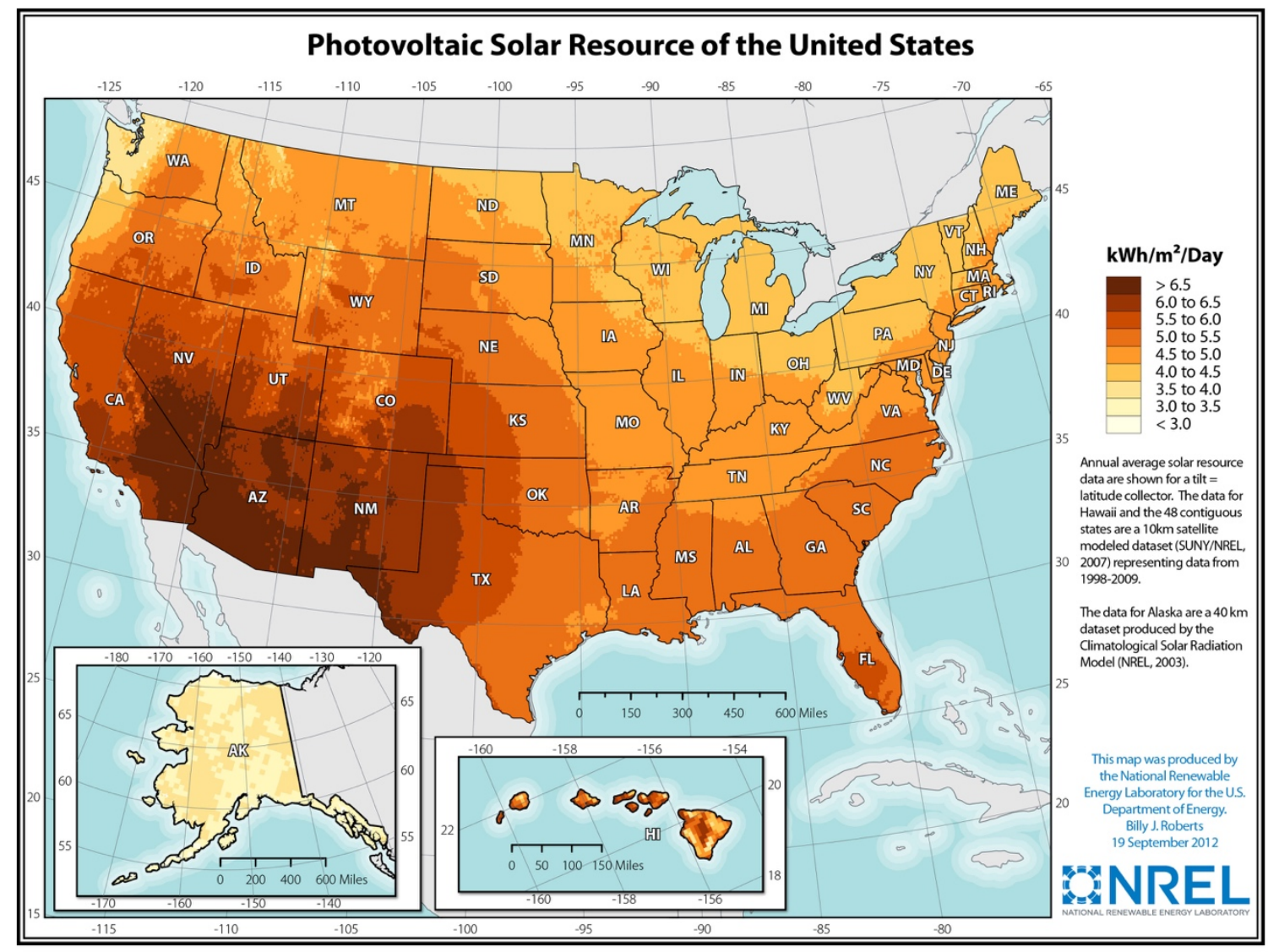

Figure 1. U.S. solar photovoltaic resource

Image credit: Billy J. Roberts, NREL

\subsection{Wind Resource}

As seen in Figure 2 (NREL 2020b), the wind resource is substantial along the nearby eastern plains of Colorado. This resource is tapped by several utilities in the corridor for the generation of electricity, as discussed in Section 2.6, Local Electric Utility Considerations. 


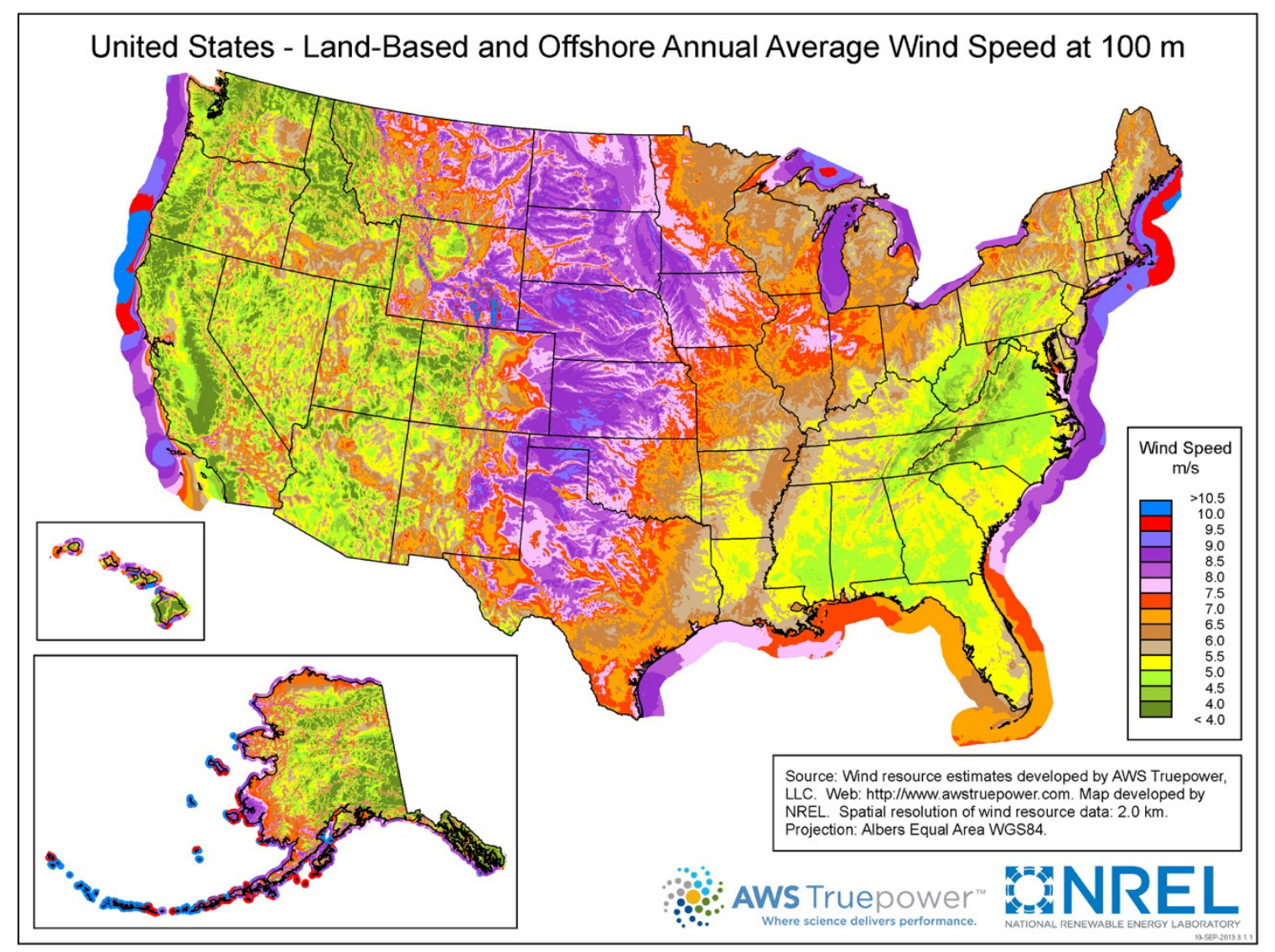

Figure 2. U.S. annual average wind speed

Image credit: NREL

\subsection{Water Resource}

Located in a semi-arid climate, precipitation in the Front Range urban corridor is less than the national average. For example, Denver experiences about 8-15 inches of precipitation per year, with the highest monthly averages occurring March through August and the lowest monthly averages occurring December through February.

Most of the water supply for the Front Range urban corridor originates as precipitation in the Rocky Mountains. Water conservation is a key strategy emphasized across the Front Range region. For example, Colorado's Water Plan "sets a measurable objective that by 2025, 75 percent of Coloradans will live in communities that have incorporated water-saving actions into land-use planning" (State of Colorado 2019).

\subsection{Building Energy Codes}

As of October 2020, Colorado is a "home rule state" with respect to building energy codes, meaning that codes are generally adopted and enforced at a local level (American Council for an Energy-Efficient Economy 2020), but with certain requirements for local jurisdictions when adopting or updating other building codes, as described by the Colorado Energy Office: 
Colorado House Bill 19-1260 updated the 2007 state law that established a minimum building energy code. Effective August 2, 2019, the law requires local jurisdictions in Colorado to adopt and enforce one of the three most recent versions of the International Energy Conservation Code (IECC) upon updating any other building code. Jurisdictions do not need to modify their timeline for adopting new building codes; they simply need to adopt one of the three most recent versions of the energy code at the same time they adopt or update other building codes, if they have them. (Colorado Energy Office 2020)

According to the Colorado Energy Office, "Approximately $76 \%$ of Colorado's population lives in jurisdictions that have adopted the 2012, 2015, or 2018 IECC" (Colorado Energy Office 2020).

Project planners should refer to their local applicable codes, laws, ordinances, and regulations to understand local requirements. Some local jurisdictions may reference an IECC code level with amendments and/or additional requirements. For example, as of October 2020, the City of Boulder requires that all projects must be designed to meet the 2020 City of Boulder Energy Conservation Code (COBECC), which is a localized version of IECC 2018 that is $20 \%$ more efficient than the national code. ${ }^{3}$ As another example, the City and County of Denver has adopted a green building ordinance, which includes a variety of options for compliance depending on the characteristics of the project (e.g., new/existing, square footage), including green space or green roofs, on-site solar panels, off-site solar energy purchase, energy conservation, green building certification, and combination approaches (City of Denver 2020).

\subsection{Local Electric Utility Considerations}

For each mixed-use multifamily project in the Front Range urban corridor, understanding the local utility's generation mix, applicable utility rates, peak period considerations, demand-side management/renewable energy programs, and greenhouse gas reduction targets can help shape specific strategies. ${ }^{4}$

In 2019, Xcel Energy's territory in Colorado had the following generation mix (Xcel Energy 2020b):

- Coal: $33 \%$

- Natural Gas: $37 \%$

- Wind: $25 \%$

- Solar: $4 \%$

- Other renewables: $1 \%$

Municipal utilities in the Front Range can have substantially different generation mixes. For example, PRPA, which serves the cities of Fort Collins, Longmont, and Loveland in the Front Range Urban Corridor, projects the following deliveries of energy in 2020 (PRPA 2020):

\footnotetext{
${ }^{3}$ See https://bouldercolorado.gov/plan-develop/energy-conservation-codes

${ }^{4}$ See "Engaging Utilities" section of A guide to Energy Master Planning of High Performance Districts and Communities (Pless et al. 2020) for a broader discussion of utility engagement strategies.
} 
- Coal: $55 \%$

- Hydroelectric: $19 \%$

- Wind: $17 \%$

- Purchased/other: $5 \%$

- Solar: $3 \%$

- Natural gas: $1 \%$

Consideration of the current generation mixes of the local electric utilities and how they might evolve in the future (see Section 1.1, Energy Related Goals in Colorado) can help prioritize strategies for energy efficiency, demand flexibility, and renewable energy. For example, as more solar and wind are installed throughout Colorado, the need for and value of demand flexibility in buildings could increase. Thus, strategies and technologies that enable flexible building loads, or at least make mixed-use multifamily buildings and districts "ready" for such technologies to be installed in the future, may be of interest. ${ }^{5}$

Understanding applicable utility rates and considering the timing of peak periods for the specific electric utility of a mixed-use development project can help to estimate energy costs and the potential value of peak load reductions and demand flexibility. For example, as of October 2020, certain residential customers in Xcel Colorado territory can enroll in an optional Time of Use (TOU) pricing plan. The "on-peak period" for this plan is 2-6 p.m. on weekdays year-round (excluding certain holidays), while the lowest price off-peak period is between 9 p.m. and 9 a.m. year-round (both weekdays and weekends). As of October 2020, the City of Fort Collins municipal utility (served by PRPA) has mandatory TOU rates for residential customers, with non-summer peak periods from 5-9 p.m. on weekdays and summer peak periods from 2-7 p.m. on weekdays (certain holidays excluded year round).

Finally, identifying applicable demand side management and renewable energy programs can shape the approaches taken in balancing efficiency and renewable energy to reach high performance levels such as zero energy. For example, in Colorado, the Xcel Energy Design Assistance Program (EDA) offers "rebates based on energy savings gained as a result of implementing equipment and systems that perform better than local code." The "Enhanced" EDA Track, which is "ideal for projects with extensive energy savings goals looking to meet green certification whether that be Leadership in Energy and Environmental Design (LEED), ENERGY STAR ${ }^{\circledR}$, or other third-party verified green building certifications," requires a commitment to achieve at least $30 \%$ minimum electric savings and $15 \%$ minimum gas savings (Xcel Energy 2020c). When such incentives are available, districts may want to target buildingscale efficiency strategies that align with and meet minimum requirements of rebate programs.

\footnotetext{
${ }^{5}$ See "Grid Integration, Energy Storage, and Electric Vehicles" section of A guide to Energy Master Planning of High Performance Districts and Communities (Pless et al. 2020) for a broader discussion on this topic.
} 


\section{Example Technical Strategies}

Considering the vision for a zero energy, all-electric, district thermal system-connected starter district outlined in Section 1 and the Colorado Front Range urban corridor conditions outlined in Section 2, this section presents example technical approaches and strategies at a high level in Section 3.1 and then in more detail for specific end uses and technology areas in Section 3.2.

\subsection{High-Level Strategies}

Mixed-use projects in the Front Range can pursue high-level strategies that guide or influence the specific strategies taken at the end-use or individual technology area levels, while leaving flexibility for innovation and customized solutions. For example, a project can set targets for Energy Use Intensities (EUIs), which are typically measured in site energy per square foot per year $\left(\mathrm{kBtu} / \mathrm{ft}^{2} / \mathrm{yr}\right)$, or can set targets for percent savings relative to business as usual practices. Projects can design for zero energy performance or pursue certification and recognition programs which have their own specific requirements. Additionally, summary specifications at the end-use level can be developed that help ensure overall performance goals are met, while leaving flexibility for building designers to implement a range of specific solutions. Below is a bulleted summary of example strategies that could be used in a Front Range multifamily-focused, mixeduse district:

1. High-level goals

A. Target ranges of EUI based on past analysis and best-in-class buildings in similar climates

- E.g., $25 \mathrm{kBtu} / \mathrm{sf} / \mathrm{yr}$ for mixed-use multifamily

B. Design for district-scale zero energy performance

C. Design for highly grid interactive and resilient buildings

D. Follow certification and recognition program guidelines such as:

- ENERGY STAR Multifamily New Construction (EPA 2020a)

- EPA Green Power Partnership (EPA 2020b)

- EPA indoor airPLUS (EPA 2020c)

- U.S. Department of Energy (DOE) Zero Energy Ready Homes (DOE 2020)

2. General strategies

A. All-electric systems

- Space heating, service and domestic hot water, cooking

- No natural gas service will be available on site, providing cost savings for infrastructure (e.g., tap fees, piping, metering)

B. High performance envelopes with continuous insulation across all opaque surfaces (walls, roof, foundations), low air leakage, and high-performance windows 
C. $100 \%$ light emitting diode (LED) lighting in residential units, shared spaces, and exterior fixtures

D. Best-in-class efficiency equipment and appliances

- ENERGY STAR and ENERGY STAR "Most Efficient” list (EPA 2020d)

E. Heat pump-based domestic hot water systems

F. Heat pump-based space conditioning that can utilize future ambient loop district thermal energy systems (if this will be a possibility)

G. Enhanced indoor air quality

- Mechanical ventilation of fresh filtered outside air provided by heat recovery ventilators (HRVs) balanced with exhaust air

- High Minimum Efficiency Reporting Value (MERV) filters in HRVs and in air handler if a forced air distribution system is used ${ }^{6}$

H. Maximize rooftop and parking canopy PV systems that can contribute to enhanced resilience, including Solar Ready Building design (Holm 2017)

I. Electric vehicle (EV) charging stations capable parking infrastructure

- Systems should meet most recent building code requirements

J. Battery energy storage systems for enhanced resilience and load flexibility.

\subsection{End-Use and Technology Area Example Strategies}

This section provides more specific descriptions of end-use and technology area strategies to accompany the high-level strategies presented in Section 3.1.

\subsubsection{Building Siting, Orientation, Shading}

While energy is not usually the primary driver for the siting and orientation of buildings within a development, there can be substantial energy implications based on how buildings are arranged and oriented. This is especially relevant in the Front Range urban corridor where solar is an abundant resource that can be harnessed on-site for power generation (using PV) and passive solar heating, but must also be managed to reduce cooling loads and control indoor lighting and glare issues. Within the constraints of the overall multifamily district project and each individual building design, developers and designers can:

- Avoid locating buildings such that they substantially shade the south-facing rooftop and façade of other buildings

- For example, locate taller buildings to the north of shorter buildings when possible

\footnotetext{
${ }^{6}$ Note that specific indoor air quality strategies tailored toward reducing the risk of community transmission of COVID-19 are currently in development may ultimately recommend additional and/or enhanced approaches. For example, see: https://www.ashrae.org/file\%20library/technical\%20resources/covid-19/covid-19-guidance-formultifamily-building-owners managers.pdf.
} 
- Orient buildings with longer axes running east/west (i.e., more north/south facing than east/west facing façade area)

- Specify external window shades that minimize direct solar gains through windows during summer to reduce cooling loads but allow direct solar gains through windows in winter to reduce heating loads ${ }^{7}$

- Consider how building locations and building-to-building shielding affects outdoor airflow and potential for natural ventilation/nighttime cooling.

To the extent allowable based on specific site context, zoning requirements, local municipality subdivision platting requirements, and various other factors, these orientation/height strategies can be considered when parceling out a mixed-use, multifamily district.

\subsubsection{Enclosure, Insulation, Air Sealing}

Enclosure specifications, including insulation levels and air tightness, will largely be driven by applicable codes, certification and recognition program requirements, and overall EUI targets. Specific strategies that can be pursued for mixed-use multifamily developments in the Front Range include:

- Meet at least the latest IECC energy code enclosure and air tightness requirements

- High performance envelope with continuous insulation across all opaque surfaces (e.g., walls, roof, foundations)

- Ensure details of continuous insulation between transitions (e.g., walls to roof, roof to foundation) and details of thermal breaks for balconies and overhangs

- Low U-value, low solar heat gain coefficient windows with non-metal window frames (e.g., fiberglass, wood, aluminum clad wood, vinyl) to reduce thermal bridging within window frame and improve interior thermal comfort

- Compartmentalize each apartment by air sealing appropriate shared interior walls to prevent cross-contamination (Lstiburek 2018)

- Air tightness testing of a representative sample of individual residential units

○ Set a target of air changes per hour at 50 pascals (ACH50) (e.g., less than 2-3 ACH50).

\subsubsection{Lighting}

- $100 \%$ LEDs in residential units, shared spaces, and exterior fixtures

- Meet the lighting power density recommendations in the Multifamily Zero Energy Design Guide (ASHRAE, forthcoming)

- Include occupancy and vacancy sensors in common spaces

- Sensors and controls that dim egress lighting to minimal levels when no occupants are present.

\subsubsection{Appliances, Equipment, and Miscellaneous Electric Loads}

- Best in class equipment and appliances

- ENERGY STAR and ENERGY STAR Most Efficient list (EPA 2020d)

\footnotetext{
${ }^{7}$ Building energy modeling can help optimize shade dimensions for each façade orientation.
} 
- In-unit clothes dryers

- For vented electric resistance clothes dryers, ducted dryer exhaust per apartment with provisions for cleaning

- Heat pump ventless clothes dryers are the most efficient all-electric in-unit dryers and can eliminate the need for dedicated dryer exhaust vents, but the humidity they add to the space should be considered. A washer/dryer mechanical room air exhaust vent connected to HRV exhaust can help address humidity issues.

- Implement best-in-class efficiency strategies for amenity space loads such as

- Variable speed pool pumps

- All-electric air source heat pump heaters for pools and hot tubs (Redwood Energy 2019, 38)

- Electric fireplace features

- ENERGY STAR appliances and devices (e.g., televisions)

○ Energy efficient, self-powered gym equipment

- Consider tenant engagement programs

- Real-time feedback of submetered power and water use

- Per-unit energy use competitions

- If tenants are submetered and billed for energy directly, some projects include a base level of monthly energy use in rent and bill extra if tenant energy use exceeds baseline

- Distribute LED bulbs to new occupants upon move-in for plug-in light fixtures

- Smart Apartment Control and tenant engagement platforms

- Integrate thermostat and access control and billing and submetering feedback

- Include per-unit water and power submetering data.

\subsubsection{Domestic Hot Water and Heating, Ventilating, and Air Conditioning}

This sub-section provides more specific strategies for domestic hot water and heating, ventilating, and air conditioning (HVAC) systems in multifamily buildings that can utilize heat pump-based district thermal energy systems. Conventional district thermal systems typically have a central plant with heating and cooling equipment (e.g., natural gas boilers, electric chillers). Hot water and chilled water are circulated in underground insulated pipes that connect to buildings and serve their heating and cooling needs. Heat pump-based systems can help access waste heat sources and sinks and enable efficient all-electric heating and cooling. Some heatpump based systems have a central heat pump and warm/chilled water is piped around the district. Other systems circulate near-ground temperature fluid in what is sometimes called an "ambient loop", and have distributed heat pumps at each building that either remove or add heat to the loop when they are in heating or cooling mode, respectively. Hot water systems can also be designed with heat pumps to utilize the shared ambient loop system. Several of the buildingscale domestic hot water and HVAC approaches identified below could potentially connect to a shared heat pump-based district thermal system.

- Service and domestic hot water

- If each unit has its own water heater, then ENERGY STAR heat pump water heaters (no electric resistance tank water heaters) 
If there is a central water heating system, then connect to low grade waste heat sources such as:

- Building or city wastewater

- Data centers

- Industrial waste heat source

- Space heating and cooling are heat pump-based and are connected to a shared water loop. Water loops can be conditioned with cooling tower, central air source heat pumps, district energy loops, or ground water heat exchangers. In-unit heating and cooling can be provided by:

○ Fan coils

$\circ$ In-unit water source heat pumps

- Some "triple-function" systems could also provide domestic hot water

○ Water-cooled variable refrigerant flow systems

○ Include setback/setup occupancy-based smart thermostats

$\circ$ Ensure in-unit heating and cooling units include multi-speed or variable-speed fans and compressors to limit short cycling and enable dehumidification capabilities

- For improved indoor air quality, filtered and conditioned mechanical ventilation balanced with exhaust from bathrooms, kitchen, and laundry room should be provided.

- Compartmentalizing ventilation and exhaust with an isolated ventilation system in each unit minimizes vertical air shafts, cross-unit air contamination, and stack effect imbalances. HRVs are recommended for Colorado's cold, dry climate to ensure exhaust heat recovery and excessive humidity buildup in winter months is sufficiently exhausted.

$\circ$ Ensure air filters are easily accessible for routine filter cleaning and replacement

- Ensure modes of operation that include balanced base minimal outside air, balanced full exhaust cases, and off modes

- HRV fresh air can be ducted to each bedroom or fresh air from HRV is mixed with return or supply air ducting of heat pump system; HRV exhausts air from bathroom and kitchen to balance

- Consider location of heat pumps and HRV in an area that is accessible without entering the apartment, such as a mechanical room with an access door in the hallway.

\subsubsection{Renewable Energy Integration}

$\mathrm{PV}$ is the most commonly used on-site renewable energy technology to help meet building and district energy needs. For very preliminary studies, use PVWatts ${ }^{\circledR}$ (NREL 2020c) to estimate annual energy production with goal of meeting 100\% of annual energy use (see Appendix A for a calculation example that includes the use of PVWatts).

Strategies for renewable energy integration include:

- Design building for PV

○ Consider the impacts of roof orientation, tilt, and architectural shading on the potential PV output

- Design structure for added weight of PV (typically $2-6 \mathrm{lb} / \mathrm{ft}^{2}$ ) and point of electrical interconnection 
○ Minimize roof-mounted building HVAC equipment; if required, install HVAC equipment along north edge of roof, including plumbing vents; target available roof area for PV at $75 \%$ or more ( $50 \%$ minimum)

- South-, southeast-, or southwest-facing roofs with a slope of at least 5 degrees that allow direct attachment of PV such as standing seam metal roofs

- Select high efficiency $(\geq 18 \%)$ PV panels

- Ensure that claims of renewable electricity use are substantiated by the building or district entity through the exclusive ownership of energy attributes or Renewable Energy Certificates (RECs) according to accepted market practices (EPA 2020e).

Incorporate load management and energy storage into the project when viable, as such efforts can greatly boost resiliency (for example, on-site PV and storage can be designed to meet critical loads when disconnected from the grid) and improve grid efficiency.

PV-covered parking should be considered if building-mounted PV does not meet all district energy needs. PV-covered parking is generally more expensive than building roof mounted PV but provides a nice amenity in the form of weather protection. Also consider PV-covered areas such as picnic and play areas. Consider adding EV charging to PV-covered parking. In Colorado, the PV-covered parking structure must be designed for the snow and wind loads.

While consumer participation in community solar projects (solar gardens) often helps the local utility meet their state compliance requirements (e.g., state renewable energy standards), at the time of this publication, most community solar projects in Colorado and other states have not conveyed the associated RECs or energy attributes directly to the project participants or sponsors. This prevents project participants or sponsors from claiming the use of renewable electricity according to accepted market practices. Thus, when exploring specific potential community solar garden projects and programs, it is important to understand whether RECs can be retained by project sponsors or participants. For large PV systems, consider a single premise power meter with the large PV system interconnected through this meter. This will require submetering with a premise billing and cost allocation system. For more information, see Appendix B, Locating Solar Photovoltaic and Renewable Systems.

\subsubsection{Electric Vehicle Charging Ready Design}

Many cities and states have aggressive goals for personal and fleet vehicle electrification. U.S. electric vehicle penetration goals have resulted in an average growth of 32\% annually from 2012 to 2016 and $45 \%$ growth during the year ending in June 2017. EV sales are forecast to reach $75 \%$ of all new car sales by 2050 if oil prices increase or technology costs decline (Pike, Steuben, and Kamei 2016; Rissman 2017). For example, the City and County of Denver set a goal that by $2030,30 \%$ of vehicles would be electric, growing to $100 \%$ of vehicles in 2050 (City of Denver 2018b). Reaching these ambitious goals will require significantly more charging stations for residents and drivers including at workplaces, homes, and apartments, as well as more public fast charging stations. With charging infrastructure build-out directly linked with EV uptake, smart EV charging infrastructure planning is a promising new energy planning practice, especially for multifamily parking infrastructure. As the installation of an EV charging station is three to four times less expensive when the infrastructure is installed during initial construction rather than as retrofits to existing buildings, multiple Front Range cities are developing new building code requirements for EV charging infrastructure (Pike, Steuben, and Hirshfield-Gold 2020). The 
emerging new construction codes that are currently being implemented across Colorado include requirements for EV-capable, EV-ready, and electric vehicle supply equipment (EVSE) installed by building type. For new multifamily projects in the Front Range, projects can focus on meeting or exceeding the local proposed building codes requiring EV charging infrastructure.

Key EV infrastructure types include (Southwest Energy Efficiency Project 2020):

1. EV capable space: A designated parking space with conduit sized for a 40-ampere (amp), 208/240-volt (V) dedicated branch circuit from a building electrical service panel to the parking space and sufficient physical space in the same building electrical service panel to accommodate a 40-amp dual-pole circuit breaker.

2. EV ready space: A parking space that is provided with one 40-amp, 208/240-V dedicated branch circuit for EV supply equipment that is terminated at a receptacle, junction box, or Level 2 EVSE within the parking space.

3. EVSE installed space: A parking space with EVSE capable of supplying Level 2 with current at 40 amps at 208/240 V. 


\section{Utilizing Strategies}

The primary objective of the document is to present example technical approaches and strategies that planners and developers can reference for all-electric mixed-use developments in the Rocky Mountain Front Range urban corridor that are considering advanced energy performance goals such as high levels of energy efficiency and renewable integration. The strategies are tailored toward the vision for a zero energy, all-electric, district thermal system-connected starter district outlined in Section 1 and the Colorado Front Range urban corridor conditions outlined in Section 2. Opportunities for utilizing or adapting these strategies include:

- Sharing with vertical developers for potential integration of strategies into vertical design guidelines

- Incorporation into Owner Project Requirements

- Provide example strategies to design team as a starting point for design

- Inform structure of agenda for a building design charrette

- Compare building designs to example strategies at various points in the design process to evaluate design progression. 


\section{References}

American Council for an Energy-Efficient Economy. 2020. "State and Local Policy Database: Energy Code Stringency." Accessed October 7, 2020. https://database.aceee.org/city/energycode-stringency.

ASHRAE. 2020. “Advanced Energy Design Guides.” Accessed September 14, 2020. https://www.ashrae.org/technical-resources/aedgs.

ASHRAE. Forthcoming. "Advanced Energy Design Guide For Multifamily Buildings Achieving Zero Energy."

Baechler, Michael, Theresa Gilbride, Pam Cole, Marye Hefty, and Kathi Ruiz. 2015. Building America Best Practices Series Volume 7.3: Guide to Determining Climate Regions by County. Richland, WA: Pacific Northwest National Laboratory. https://www.energy.gov/sites/prod/files/2015/10/f27/ba climate region guide 7.3.pdf.

City of Denver. 2013. "Sun Valley Neighborhood Decatur-Federal Station Area Plan.” April 22, 2013.

https://www.denvergov.org/content/dam/denvergov/Portals/646/documents/planning/Plans/Decat ur_Federal_station_area plan.pdf.

City of Denver. 2018a. Denver Releases $80 x 50$ Climate Action Plan. Press release, July 17, 2018. https:/www.denvergov.org/content/denvergov/en/mayors-office/newsroom/2018/denverreleases-80x50-climate-action-plan.html.

City of Denver. 2018b. "Denver 80x50 Climate Action Plan.” July 17, 2018.

https://www.denvergov.org/content/dam/denvergov/Portals/771/documents/EQ/80x50/80x50_Cl imatePlan 7.17.18.pdf.

City of Denver 2020. “Green Buildings Ordinance.” Accessed September 11, 2020.

https://www.denvergov.org/content/denvergov/en/denver-development-services/commercialprojects/green-roof-initiative.html.

Colorado Energy Office. 2020. "Building Energy Codes.” Accessed September 11, 2020. https://energyoffice.colorado.gov/climate-energy/energy-policy/building-energy-codes.

Colorado General Assembly. 2019. House Bill 19-1261, “Climate Action Plan To Reduce Pollution." https://leg.colorado.gov/bills/hb19-1261.

DOE. 2020. "Guidelines for Participating in the DOE Zero Energy Ready Home Program." Accessed September 11, 2020. https:/www.energy.gov/eere/buildings/guidelines-participatingdoe-zero-energy-ready-home-program.

EPA. 2020a. "ENERGY STAR Multifamily New Construction Certification Process." Accessed September 11, 2020.

https://www.energystar.gov/partner_resources/residential_new/program_reqs/mfnc_cert_process. 
EPA. 2020b. "Green Power Partnership.” Accessed September 11, 2020.

https://www.epa.gov/greenpower.

EPA. 2020c. "Indoor airPLUS." Accessed September 11, 2020.

https://www.epa.gov/indoorairplus.

EPA. 2020d. "ENERGY STAR Most Efficient 2020.” Accessed September 14, 2020.

https://www.energystar.gov/products/most efficient.

EPA. 2020e. "What is Green Power?" Accessed September 14, 2020.

https://www.epa.gov/greenpower/what-green-power.

EPA. 2020f. "Use Portfolio Manager." Accessed September 14, 2020.

https://www.energystar.gov/buildings/facility-owners-and-managers/existing-buildings/useportfolio-manager.

Griffith, B., N. Long, P. Torcellini, R. Judkoff, D. Crawley and J. Ryan. 2007. Assessment of the Technical Potential for Achieving Net Zero-Energy Buildings in the Commercial Sector. Golden, CO: National Renewable Energy Laboratory. https://www.nrel.gov/docs/fy08osti/41957.pdf.

Holm, Allison. 2017. "Solar-Ready Building Design: A Summary of Technical Considerations." https://www.nrel.gov/state-local-tribal/blog/posts/solar-ready-building-design-a-summary-oftechnical-considerations.html.

Langner, Rois, Paul Torcellini, Matthew Dahlhausen, David Goldwasser, Joe Robertson, and Sarah Zaleski. 2020. "Transforming New Multifamily Construction to Zero: Strategies for Implementing Energy Targets and Design Pathways." 2020 American Council for an EnergyEfficient Economy Summer Study on Energy-Efficient Buildings.

Linsley-Hood, David. 2020. "Decarbonising heat using ambient loop heat networks." CIBSE Journal, July 2020. https://www.cibsejournal.com/technical/take-it-down-low/.

Lstiburek, Joseph. 2018. "BSI-108: Are We Sealing The Right Walls In Buildings*?" Building Science Corporation Insights, December 18, 2018.

https://www.buildingscience.com/documents/building-science-insights/bsi-108-are-we-sealingright-walls-buildings.

NREL. 2017. Microgrid-Ready Solar PV - Planning for Resiliency. Golden, CO: NREL. https://www.nrel.gov/docs/fy18osti/70122.pdf.

NREL. 2020a. "Solar Resource Data, Tools, and Maps." Accessed September 11, 2020. https://www.nrel.gov/gis/solar.html.

NREL. 2020b. "Wind Resource Data, Tools, and Maps.” Accessed September 11, 2020. https://www.nrel.gov/gis/wind.html.

NREL. 2020c. "PVWatts Calculator.” Accessed September 14, 2020. https://pvwatts.nrel.gov/. 
Peterson, Kent, Paul Torcellini, and Roger Grant. 2015. “A Common Definition for Zero Energy Buildings." Washington, DC: U.S. Department of Energy.

https://www.energy.gov/sites/prod/files/2015/09/f26/bto_common_definition_zero_energy_build ings 093015.pdf.

Pike, Ed, Jeffrey Steuben, and Evan Kamei. 2016. "Plug-In Electric Vehicle Infrastructure CostEffectiveness Report for San Francisco." San Francisco, CA: Energy Solutions and Pacific Gas \& Electric Company. http://evchargingpros.com/wp-content/uploads/2017/04/City-of-SF-PEVInfrastructure-Cost-Effectiveness-Report-2016.pdf.

Pike, Ed, Jeffrey Steuben, and Shayna Hirshfield-Gold. 2020. California Energy Commission Clean Transportation Program Final Project Report: City of Oakland Plug-in Electric Vehicle Readiness Grant. Oakland, CA: City of Oakland. https://ww2.energy.ca.gov/2020publications/CEC-600-2020-FTD/CEC-600-2020-116.pdf.

Pless, Shanti, Ben Polly, and Sarah Zaleski. 2018. "Communities of the Future: Accelerating Zero Energy District Master Planning." Paper presented at the 2018 ACEEE Summer Study on Energy Efficiency in Buildings, Pacific Grove, California, August 12-17, 2018. https://www.nrel.gov/docs/fy18osti/71841.pdf.

Pless, Shanti, Ben Polly, Sammy Houssainy, Paul Torcellini, William Livingood, Sarah Zaleski, Matt Jungclaus, Tom Hootman, and Mindy Craig. 2020. A Guide to Energy Master Planning of High-Performance Districts and Communities. Golden, CO: National Renewable Energy Laboratory. NREL/TP-5500-78495. https://www.nrel.gov/docs/fy21osti/78495.pdf.

PRPA. 2018. Platte River Board passes energy policy. Press release, December 6, 2018. https://www.prpa.org/media-releases/platte-river-board-passes-energy-policy/.

PRPA. 2020. "Sources of Electricity." Accessed October 8, 2020. https://www.prpa.org/generation/.

Redwood Energy. 2019. “A Zero Emissions All-Electric Multifamily Construction Guide.” https://fossilfreebuildings.org/ElectricMFGuide.pdf.

Rissman, Jeffrey. 2017. "The Future of Electric Vehicles in the U.S.” San Francisco, CA: Energy Innovation Policy and Technology LLC. https://energyinnovation.org/wpcontent/uploads/2017/09/2017-09-13-Future-of-EVs-Research-Note_FINAL.pdf.

Southwest Energy Efficiency Project. 2020. “Electric Vehicles.” Accessed September 14, 2020. https://www.swenergy.org/transportation/electric-vehicles.

State of Colorado. 2019. "Colorado’s Water Plan: Frequently Asked Questions.” Accessed September 11, 2020. https://www.colorado.gov/pacific/cowaterplan/frequently-asked-questions.

Svaldi, Aldo. 2019. "Denver apartment development booming despite signs of slowdown." Denver Post, February 9, 2019. https://www.denverpost.com/2019/02/09/denver-apartmentdevelopment-boom/. 
U.S. Census Bureau. 2020. “County Population Totals: 2010-2019.” Accessed October 9, 2020. https://www.census.gov/data/tables/time-series/demo/popest/2010s-counties-total.html

VISIT DENVER. 2020. “Weather \& Climate Info.” Accessed September 11, 2020.

https://www.denver.org/about-denver/denver-resources/weather/.

Xcel Energy. 2020a. "Building a Carbon-Free Future.” Accessed September 11, 2020. https://www.xcelenergy.com/environment/carbon_reduction_plan.

Xcel Energy. 2020b. "Power Generation.” Accessed October 8, 2020.

https://www.xcelenergy.com/energy portfolio/electricity/power_generation.

Xcel Energy. 2020c. "Business New Construction.” Accessed October 7, 2020.

https://www.xcelenergy.com/staticfiles/xe-

responsive/Admin/Managed\%20Documents\%20\&\%20PDFs/CO-Bus-Business-New-

Construction-Info-Sheet.pdf. 


\section{Appendix A. Example Zero Energy Calculation for an All-Electric District}

DOE has outlined a common definition for Zero Energy Buildings, Campuses, and Communities. The following definition for campuses is most relevant to zero energy districts (Peterson, Torcellini, and Grant 2015):

Zero Energy Campus: An energy-efficient campus where, on a source energy basis, the actual annual delivered energy is less than or equal to the on-site renewable exported energy.

Note that for on-site renewable energy projects, the zero energy definition requires that all of the associated RECs generated by the project be retained or retired. For an all-electric district, one can calculate the amount of annual renewable energy generation needed to reach zero energy by estimating the annual electricity consumption within the district. ${ }^{8}$ For example, given the preliminary architectural program shown in the table below for the Sun Valley Starter District, the total annual electric energy consumption can be estimated by multiplying the total square footage for each building by the estimated annual EUI $\left(\mathrm{kBtu} / \mathrm{ft}^{2} / \mathrm{yr}\right)$ for each building.

A variety of methods can be used to estimate achievable EUIs for each building type, including:

- Analyzing measured data from similar past projects in similar climates. ${ }^{9}$ This type of analysis can be facilitated by EPA's ENERGY STAR Portfolio Manager (EPA 2020f)

- Leveraging EUI information contained in the ASHRAE Advanced Energy Design Guides (AEDGs)(ASHRAE 2020)

- Modeling the buildings and/or district using building energy simulation tools.

If this preliminary type of analysis is applied to potential Sun Valley multifamily building designs, there are indicated achievable site EUIs in the upper 20's $\left(\mathrm{kBtu} / \mathrm{ft}^{2} / \mathrm{yr}\right)$ for the living space within the multifamily apartment buildings. A broader and more detailed ongoing analysis for the forthcoming Multifamily Zero Energy Design Guide (not specific to Sun Valley) indicates mixed-use multifamily site EUIs in the mid-to-lower 20's $\left(\mathrm{kBtu} / \mathrm{ft}^{2} / \mathrm{yr}\right)$ may be achievable in climates like Denver (Langner et al. 2020). Thus, an example target EUI of 25 $\mathrm{kBtu} / \mathrm{ft}^{2} / \mathrm{yr}$ is used for the apartment buildings in this example calculation. These EUIs assume typical multifamily occupancy and specific construction details for energy-related features (e.g., enclosures, HVAC, water heating equipment, lighting, appliances, and miscellaneous electric loads). Final EUI targets may be adjusted based on more customized assumptions about occupancy, construction details, and so forth as design details advance for the Sun Valley Starter District. Analysis for user-specific commercial buildings will be highly dependent on the prescribed programming within such buildings in order to propose a target EUI. For the smaller commercial buildings contemplated in this program, an example target EUI of $40 \mathrm{kBtu} / \mathrm{ft}^{2} / \mathrm{yr}$ is

\footnotetext{
${ }^{8}$ Since exported electricity is assumed to have the same source energy conversion factor as delivered electricity from the grid, a source energy calculation is not needed.

${ }^{9}$ Similar efficiency details, building use types, occupancy levels, etc.
} 
assumed so that the overall calculation method can be demonstrated. The following example considers a three-building district-based approach:

Table A-2. Example Three-Building Starter District

\begin{tabular}{|l|r|r|r|r|}
\hline & & \multicolumn{3}{|c|}{$\begin{array}{l}\text { Example } \\
\text { Target EUI }\end{array}$} \\
Phase & Area (SF) & $\begin{array}{l}\text { (kBtu/sf/yr) } \\
\text { (kBtu/yr }\end{array}$ & MWh/yr \\
\hline Apartment 1 & 145,000 & 25 & $3,625,000$ & 1,062 \\
\hline Apartment 2 & 145,000 & 25 & $3,625,000$ & 1,062 \\
\hline Commercial 1 & 14,000 & 40 & 560,000 & 164 \\
\hline $\begin{array}{l}\text { Other Assumed } \\
\text { District Loads }\end{array}$ & N/A & N/A & & 0 \\
\hline TOTAL & 304,000 & & $7,810,000$ & 2,289 \\
\hline
\end{tabular}

The PVWatts tool can be used to provide very preliminary estimates ${ }^{10}$ of the annual generation for $1 \mathrm{MW}$ DC of south facing roof-mounted solar at the location of interest. A screen shot of the PVWatts tool is shown in Figure A-3. Entering the following inputs for a location near the Sun Valley Starter District yields the accompanying estimate:

- $\quad$ DC system size $(\mathrm{kW}): 1,000$ (1 MW)

- Module type: standard

- Array type: fixed (roof mount)

- System losses (\%): 14.08

- Tilt (deg): 20

- Azimuth (deg): 180 (south facing)

- $\quad$ DC to AC size ratio: 1.2

- Inverter efficiency (\%): 96

- Ground coverage ratio: 0.4

- Estimated annual electricity generation: 1,508,657 kWh/yr (1,509 MWh/yr).

This process can be repeated to estimate annual generation for fixed (open rack) ground-mounted solar, which yields slightly more generation per MW-DC system size: 1,531 MWh/yr. An average value of $1,520 \mathrm{MWh} / \mathrm{yr}$ can be used for further calculations since the values are within $2 \%$.

\footnotetext{
${ }^{10}$ Important Note: PVWatts is suitable for very preliminary studies of a PV system that uses modules (panels) with crystalline silicon or thin film PV cells. PVWatts production estimates do not account for many factors that are important in the design of a PV system. If you are using PVWatts to help design a system, you should work with a qualified professional to make final design decisions based on an assessment of the system location and using more detailed engineering design and financial analysis tools.
} 
The total annual electricity energy consumption for the district can be divided by the estimated annual production per MW-DC of rooftop PV capacity:

2,289 MWh/yr * 1/(1,520 MWh/yr/MW-DC) = approximately 1.506 MW-DC system size (roof mount and/or ground mount, south facing).

Currently, commercial PV panel efficiency often ranges from around $16 \%$ to $23 \%$. Assuming a $20 \%$ efficient PV panel, the panel area is about $1,506 \mathrm{~kW} * 1 /\left(1 \mathrm{~kW} / \mathrm{M}^{2} * 0.2\right)=$ approximately $7,529 \mathrm{M}^{2}=$ approximately $81,040 \mathrm{ft}^{2}$. The actual area required is larger because of the space between panels and rows of panels. Typical commercial PV panels are about $400 \mathrm{~W}$ each, so about 3,765 PV panels are required for $1,506 \mathrm{~kW}$. Because of site constraints, it may not be possible to fit all of the $\mathrm{PV}$ within the starter district site boundaries. In this case a combination of on-site and off-site solar may be needed (see Appendix B, Locating Solar Photovoltaic and Renewable Systems).

PVWatts could be used to investigate other scenarios such as rooftop solar with different orientations and ground-mount systems with tracking. In this simple analysis, only the electricity consumption associated with the buildings is considered. If other electrical loads are expected within the scope of the district (e.g., street and open space lighting), these loads can be estimated and included in the calculation which would increase the estimated size of the PV.

The EUIs above assumed efficient electric heating systems, such as ground source heat pumps or heat pumps with a sewer water heat recovery system. The vision for the Sun Valley Starter District is a shared heat pump-based district thermal system. In order to estimate the capacity and number of bore holes needed for a shared ground source system, more detailed estimates of building thermal loads can be developed as building designs evolve and solidify. A test well and experts in ground source systems and the local geology may be needed to develop these estimates. 


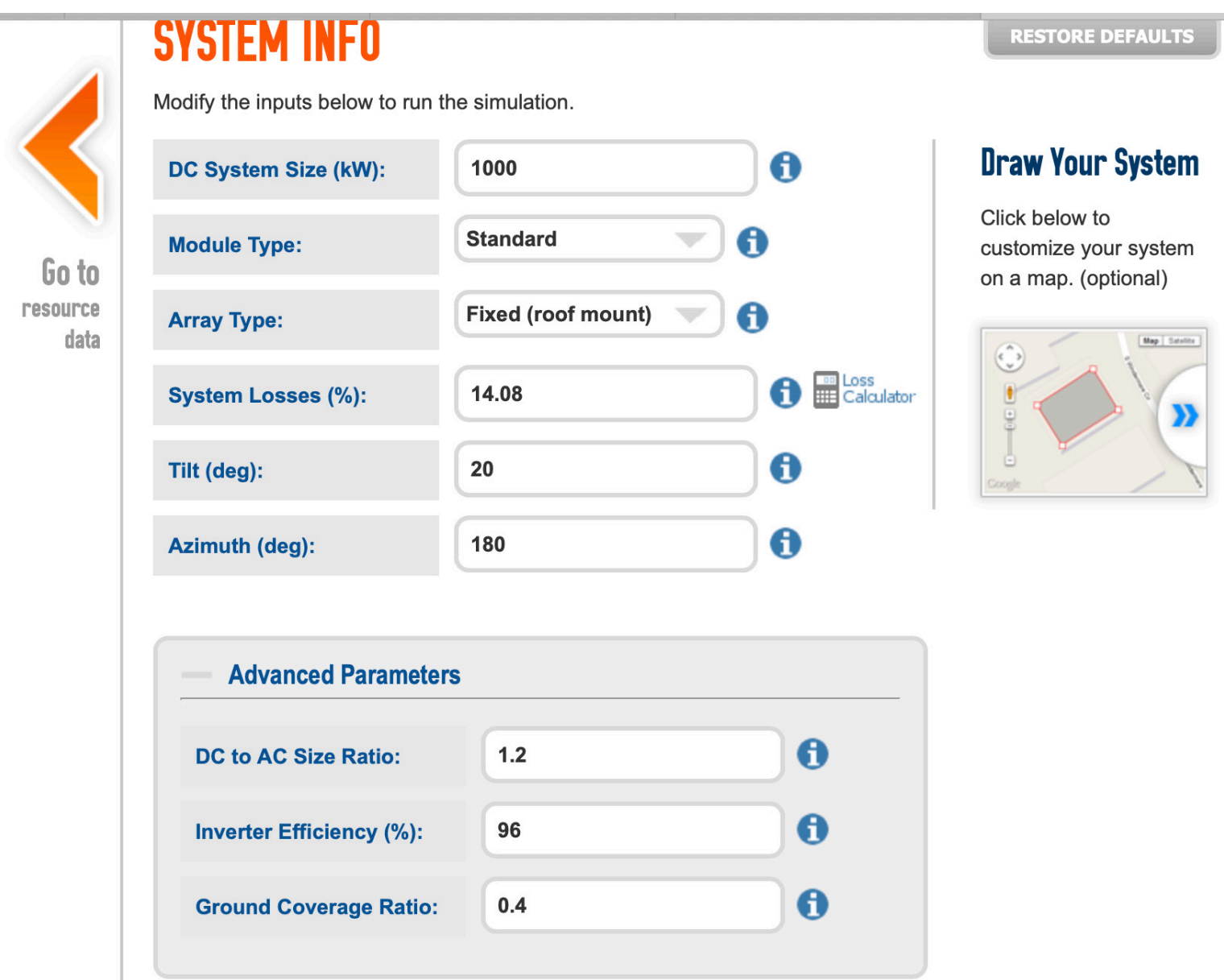

\section{RETAIL ELECTRICITY RATE}

To automatically download an average annual retail electricity rate for your location, choose a rate type (residential or commercial). You can change the rate to use a different value by typing a different number.

Rate Type:

Rate (\$/kWh):

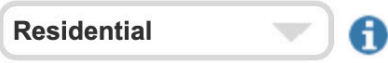

0.111

Figure A-3. PVWatts assumptions for example calculation

Image credit: NREL 


\section{Appendix B. Locating Solar Photovoltaic and Renewable Systems}

To reach aggressive district-wide energy goals, such as zero energy, significant on-site and/or off-site renewable energy systems will be necessary. Therefore, all viable and cost-effective PV solutions, from 2-kW single family residential rooftop systems to 10-MW ground mount tracking solar PV systems will need to be explored. In general, PV integrated into or installed on buildings and parking produce local electricity that can directly offset a building's retail electricity costs, help support a building-scale resilience investment (NREL 2017), and be integrated into the design and construction process for a new building construction project. In most climate zones, energy-efficient, low-load, low- and medium- rise buildings such as offices, multifamily buildings of four floors or fewer, and single family homes can potentially reach their energy goals with building interconnected PV (Griffith et al. 2007). However, there is simply not enough rooftop to fit the number of solar panels needed on most taller buildings ( $\geq 5$ stories), and many urban areas have too much shading for panels on vertical facades and or on solar carports. Therefore, offsite renewable energy solutions will be needed for some buildings and districts. The figure below shows some examples of options available to many consumers. ${ }^{11}$

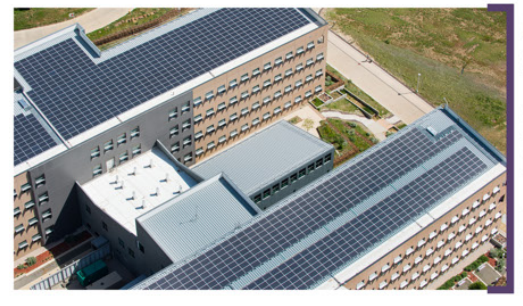

Maximize rooftop solar photovoltaics by targeting $50 \%$ $75 \%+$ rooftop coverage. $75 \%+$ coverage is possible if planned from the beginning using solar ready buildings guidance.

NREL Research Support Facility zero energy office building with maximized rooftop solar photovoltaics. Photo by Dennis Schroeder, NREL 37833

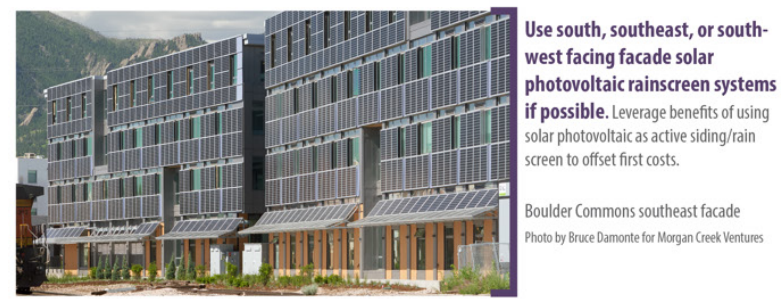

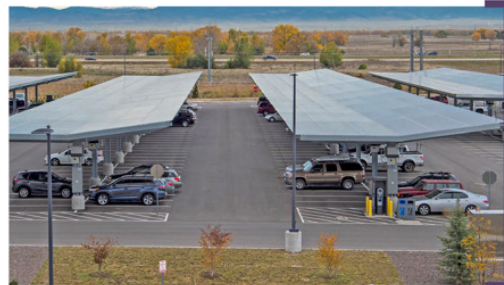

Consider solar photovoltaics canopy for surface parking and parking garage. Leverage benefits of snow control, hail protection, and ain and sun shelters to help cost justify structure investment. Can be connected to buildings directly or part of a district shared system. Peña Station Next shared surface parking lot PV canopy shared across district buildings. Thoto by Dennis Schroeder, NREL 48749

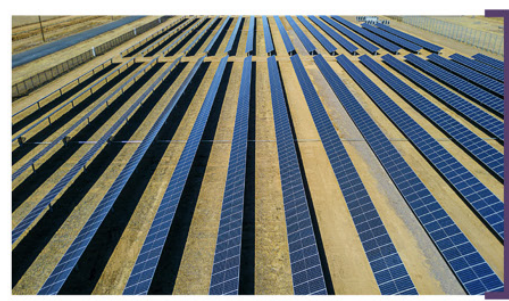

Develop off-site local and community shared solar photovoltaics systems. Often directly owned by district buildings or purchased as a virtual power purchase ggreement.

Denver Housing Authority community solar garden allocated to low-income Denver public housing members. enver public housing members.

Figure A-4. Examples of PV options

Figure credit: Pless et al. 2020

Options for acquiring offsite renewables may vary based on a consumer's access to different supply options. Furthermore, if a district is pursuing zero energy certification or recognition, it is important to be aware that several emerging programs set their own guidance for locating renewable systems for zero energy buildings and districts. The Zero Code, USGBC's LEED Zero program, and the International Living Future Institute's Zero Energy Certification program, each provide guidance for developing a renewable location planning strategy. For example, The

\footnotetext{
${ }^{11}$ See https://www.epa.gov/greenpower/green-power-supply-options for a more complete list of options.
} 
Zero Code provides multipliers, or weightings, for how each renewable location is to be prioritized and allocated to reach the zero energy goal (see Table A-3).

Table A-3. Summary of Zero Code Renewable Energy Allocation for On-Site and Off-Site Renewable Options ${ }^{12}$

\begin{tabular}{|l|l|}
\hline Renewable System Type & Coefficient Allocation \\
\hline On-Site Renewables & 1.0 \\
\hline $\begin{array}{l}\text { Self-Owned Off-Site } \\
\text { Community Solar with Retained RECs } \\
\text { Virtual Power Purchase Agreements within Balancing Authority } \\
\text { Green Retail Tariffs or Direct Access with Bundled RECs }\end{array}$ & 0.9 \\
\hline $\begin{array}{l}\text { Green Retail Tariffs or Direct Access } \\
\text { Virtual Power Purchase Agreements Out of Region }\end{array}$ & 0.6 \\
\hline Unbundled RECs & 0.5 \\
\hline
\end{tabular}

For any of these classes of renewables, there is a growing interest in understanding the hourly alignment of on-site and off-site renewable energy generation with building electric loads. As more renewables are added into the energy systems, there is an interest in understanding opportunities to align building loads with this generation through strategies such as load management, electrification of new loads, and energy storage. In addition, addressing the grid integration of zero energy buildings can help to reduce peak demand charges and minimize premium energy charges associated with time-of-use rates.

12 Adapted from http://zero-code.org/wp-content/uploads/2020/11/ZERO-Code-2.0.pdf. 